\title{
PERILAKU PASIEN DIABETES MELITUS DALAM UPAYA PENCEGAHAN KAKI DIABETIK
}

\author{
Sejana, I Nyoman ${ }^{1}$; Widyanata, Komang Agus Jerry ${ }^{2 *}$; Rahayu, V.M Endang Sri \\ Purwadmi $^{3}$; Dira, I Ketut ${ }^{4}$ \\ ${ }^{1,2,4}$ Akademi Keperawatan Kesdam IX/Udayana \\ ${ }^{3}$ Politeknik Kesehatan Denpasar \\ *Korespondensi: jerrywidyanata@yahoo.com
}

\begin{abstract}
Background: Diabetes Mellitus is a disease with high levels of glucose (simple sugar) in the high blood because the body can not release or use insulin adequately. One complication that is feared by people with Diabetes is Diabetic Foot or Diabetic Gangrene. This research aims to determine the behavior of patients with diabetes mellitus in the prevention of diabetic foot in room of Sahadeva and Nakula Sanjiwani Gianyar District Hospital. Methods: Types of research used in this research is descriptive survey approach. Sample of the study are 40 patients with diabetes mellitus hospitalized in the room of Sahadeva and Nakula Sanjiwani Gianyar District Hospital using consecutive sampling technique. Data is collected in the period March to May 2012 by filling out a questionnaire about behavioral prevention of diabetic foot. Results: The results of data analysis showed that the behavior of patients with Diabetes Mellitus in the prevention of Diabetic Foot based on education level, age, gender and occupation. From the 40 respondents there were: 55\% of the level of knowledge good, $80 \%$ good attitude, $70 \%$ good actions and 67,5\% good actions in the category of good behavior. Conclusion: It can be concluded that the behavior of patients with Diabetes Mellitus in the prevention of Diabetic Foot is in a good category with the factors assessed including knowledge, attitudes, and actions.
\end{abstract}

Keywords : Diabetes mellitus; diabetic foot; behavioral

\begin{abstract}
ABSTRAK
Latar belakang: Diabetes melitus adalah suatu penyakit dengan kadar glukosa (gula sederhana) di dalam darah tinggi karena tubuh tidak dapat melepaskan atau menggunakan insulin secara cukup. Salah satu komplikasi yang sangat ditakuti oleh penderita diabetes adalah kaki diabetik atau gangren diabetes. Penelitian ini bertujuan untuk mengetahui perilaku pasien diabetes melitus dalam upaya pencegahan kaki diabetik di Ruang Sahadewa dan Nakula RSUD Sanjiwani Gianyar. Metode: Jenis penelitian yang digunakan dalam penelitian ini adalah deskriptif dengan pendekatan survey. Sampel penelitian yang digunakan adalah pasien diabetes melitus yang rawat inap di ruang Sahadewa dan Nakula RSUD Sanjiwani Gianyar sebanyak 40 orang
\end{abstract}


dengan menggunakan teknik consecutive sampling. Pengambilan data dilakukan pada periode bulan Maret hingga Mei 2012 dengan cara pengisian kuesioner tentang perilaku pencegahan kaki diabetik. Hasil: Hasil analisa data menunjukan bahwa perilaku pasien diabetes melitus dalam upaya pencegahan kaki diabetik berdasarkan tingkat pendidikan, usia, jenis kelamin dan pekerjaan. Data menunjukan terdapat $55 \%$ tingkat pengetahuannya baik, $80 \%$ sikapnya baik, $70 \%$ tindakannya baik dan $67,5 \%$ perilakunya dalam kategori baik. Simpulan: Dapat disimpulkan bahwa perilaku pasien DM dalam pencegahan kaki diabetik masuk dalam kategori baik dengan faktor yang dinilai meliputi pengetahuan sikap, dan tindakan.

\section{Kata kunci: Diabetes Mellitus; kaki diabetes; perilaku}

\section{PENDAHULUAN}

Salah satu komplikasi yang sangat ditakuti oleh penderita diabetes adalah kaki diabetik atau gangren diabetes. Kaki diabetik adalah adanya tukak atau borok atau kerusakan jaringan dalam, berhubungan dengan kelainan saraf, dan pembuluh darah pada tungkai bawah (Soegondo, 2006). Seiring dengan meningkatnya jumlah penyandang diabtes melitus, maka prevalensi kaki diabetik diperkirakan akan meningkat juga. Banyak faktor yang berkaitan dengan kaki diabetik yaitu neuropati, infeksi dan kelainan vaskuler, sehingga pengelolaan yang diberikan disesuakan dengan mekanisme yang mendasari atau yang dominan (PERKENI, 2009). Adanya kerentanan terhadap infeksi menyebabkan infeksi mudah merobek menjadi infeksi yang lebih luas. Faktor aliran darah yang kurang juga akan lebih lanjut menambah rumitnya pengelolaan kaki diabetes (Sudoyo, 2006).

Komplikasi kaki diabetik merupakan komplikasi kronik diabetes melitus yang paling ditakuti karena tindakan amputasi. Kasus ulkus dan gangren diabetik merupakan kasus diabetes melitus yang paling banyak dirawat di rumah sakit. Diperkirakan sekitar sepertiga dari pasien diabetes melitus akan mengalami masalah kaki. Lamanya perawatan, besarnya biaya dan tindakan amputasi yang merupakan kegagalan pengelolaan merupakan faktor - faktor yang mendesak perlu dihentikannya kasus kaki diabetik ini dengan sebaik - baiknya. Sebanyak 30-50\% pasien pasca amputasi akan menjalani amputasi pada kaki sisi lainnya dalam kurun waktu 1-3 tahun (PERKENI, 2009). 
Komplikasi kaki diabetik dapat dicegah dengan menerapkan hal-hal sebagai berikut : a) Periksa kaki anda secara teratur setiap hari, terutama pada telapak kaki dan ruang antar jari, b) Cuci kaki anda setiap hari dengan sabun yang lembut, c) Potonglah kuku-kuku di jari kaki anda dengan hati-hati dan tidak terlalu dalam, d) Olesi kaki dengan krim pelembab agar tidak retak, e) Gunakan alas kaki setiap berjalan, f) Pilih kaus kaki dengan kandungan katun yang tinggi sehingga menyerap keringat dan tidak mudah mengiritasi, g) Periksakan diri anda secara rutin ke dokter (majalahkesehatan, 2012). Perilaku manusia secara operasional dapat dikelompokan menjadi tiga domain, yaitu perilaku dalam bentuk pengetahuan, sikap, dan tindakan nyata atau perbuatan. Pengetahuan merupakan hasil mengingat suatu hal termasuk mengingat kembali kejadian yang pernah dialami baik secara sengaja maupun tidak disengaja dan ini terjadi setelah orang melakukan kontak atau pengamatan terhadap suatu objek tertentu. Sikap merupakan reaksi atau respon seseorang terhadap suatu stimulus atau objek. Tindakan merupakan perwujudan nyata dari sikap (Mubarak, 2006:28). Upaya pencegahan dapat dilakukan dengan benar apabila pasien mempunyai dasar perilaku (Kognitif, Efektif dan Psikomotor) yang jelas tentang cara perawatan dan pencegahan kaki diabetik (Mubarak, 2006).

Tujuan dari penelitian ini adalah untuk mengetahui perilaku pasien Diabetes Mellitus dalam upaya pencegahan kaki Diabetik di Ruang Sahadewa dan Nakula RSUD Sanjiwani Gianyar

\section{METODE}

Desain yang digunakan dalam penelitian ini adalah penelitian deskriptif dengan pendekatan survey yaitu jenis pendekatan yang menekankan pada pengumpulan informasi tanpa memberikan intervensi melalui penyebaran kuisioner kepada responden berkaitan penerapan diet sehari-hari. (Notoadmojo, 2010). Populasi dalam penelitian ini adalah pasien DM tipe 2 di Ruang Sahadewa dan Nakula RSUD Sanjiwani Gianyar yaitu sebanyak 62 orang pada bulan Mater - Mei 2012. Sampel pada penelitian ini sebanyak 40 orang didapatkan menggunakan rumus besar sampel $\mathrm{n}$ (Nursalam, 2010). Tehnik sampling yang digunakan adalah consecutive sampling 
dimana setiap pasien yang memenuhi kriteria inklusi telah dimasukkan dalam penelitian (Nursalam, 2008), dalam kurun waktu bulan Maret sampai Mei 2012.. Pasien dimasukan sebagai responden jika pasien bersedia menjadi responden, mampu membaca dan menulis serta kooperatif dan dikeluarkan jika pasien DM dengan komplikasi kaki diabetik dan mengalami komplikasi akut dan kronis lainya.

Instrumen yang digunakan dalam penelitian ini adalah menggunakan lembar kuesioner yang terdiri dari empat bagian, yaitu bagian pertama tentang data demografi responden yang mencakup tingkat pendidikan, umur, jenis kelamin, dan pekerjaan. Dalam kuesioner bagian kedua terdiri dari 10 item pertanyaan untuk data pengetahuan, pertanyaan berbentuk pernyataan tertutup yang menggunakan skala Guttman yaitu dengan memberikan jawaban yang tegas benar nialai 1 atau salah nilai 0 terhadap suatu permasalahan yang ditanya (Sugiyono, 2001), bagian ketiga terdiri 5 item pernyataan untuk data sikap, yaitu berbentuk pernyataan tertutup yang menggunakan Skala Likert. Pada bagian keempat terdiri dari 10 item pertanyaan untuk data tindakan dimana untuk pengukuran tindakan teknik yang paling akurat yaitu observasi langsung namun karena keterbatasan waktu, tenaga, dan biaya maka teknik yang digunakan dalam penelitian ini yaitu adalah melalui pengisisan lembar kuesioner dengan 5 pilihan menggunakan Skala Linkert. Data yang sudah dikumpulkan kemudian dimasukkan ke dalam tabel induk sesuai dengan jawaban yang telah diberikan oleh responden dan dilakukan pengkodean, kemudian dianalisa dengan analisa statistik deskriptif.

\section{HASIL}

Berdasarkan tabel 1, dapat dilihat karakteristik responden yang menjadi sampel dalam penelitian ini adalah pasien diabetes melitus berusia 20 - 70 tahun. Data yang diperoleh yaitu sebagian besar berusia 41 - 60 tahun sebanyak 27 responden (67,5\%), dengan tingkat pendidikan SD sebanyak 17 responden (42,5\%), jenis kelamin kebanyakan perempuan yaitu 22 responden $(55 \%)$ dan pekerjaannya petani yaitu sebanyak 23 responden $(57,5 \%)$. 
Berdasarkan data hasil penelitian yang telah didapat, menunjukan bahwa kebanyakan responden memiliki perilaku yang baik dalam upaya pencegahan kaki diabetik yaitu sebanyak 67,5\% dan kategori sangat baik sebanyak 5\%, namun dari data juga dapat dilihat sebanyak $27,5 \%$ masih memiliki perilaku dalam kategori cukup. Dilihat dari pengetahuannya kebanyakan responden memiliki pegetahuan dalam kategori baik yaitu sebanyak 55\%. Berdasarkan sikap responden dalam upaya mencegah kaki diabetik didapatkan data $80 \%$ responden memiliki sikap baik. Dan tindakan responden dalam upaya pencegahan kaki diabetik menunjukan bahwa kebanyakan responden memiliki tindakan dalam kategori baik yaitu sebanyak $70 \%$. Tetapi masih ada responden yang memiliki perilaku (pengetahuan, sikap dan tindakan) yang tergolong dalam kategori cukup yaitu sebanyak 27,5\%.

Tabel 1. Karakteristik responden di Ruang Sahadewa dan Nakula RSUD Sanjiwani Gianyar, Tanggal 17 Maret - 30 Mei 2012

\begin{tabular}{ccccccccc}
\hline No & $\begin{array}{l}\text { Umur } \\
\text { (tahun) }\end{array}$ & $\%$ & Sex & $\%$ & Pendidikan & $\%$ & Pekerjaan & $\%$ \\
\hline 1 & $20-40$ & 2,5 & Laki-laki & 45,0 & SD & 42,5 & PNS & 7,5 \\
2 & $41-60$ & 67,5 & Perempuan & 55,0 & SMP & 32,5 & Swasta & 22,5 \\
3 & $61-70$ & 30,0 & & & SMA & 17,5 & Petani & 57,5 \\
4 & & & & PT & 7,5 & Tidak bekerja & 12,5 \\
\hline \multicolumn{2}{l}{ Total } & $\mathbf{1 0 0}$ & & $\mathbf{1 0 0}$ & & $\mathbf{1 0 0}$ & & $\mathbf{1 0 0}$ \\
\hline
\end{tabular}

Tabel 2. Gambaran Pengetahuan Responden Mengenai Upaya Pencegahan Kaki Diabetik di Ruang Sahadewa dan Nakula RSUD Sanjiwani Gianyar, Maret - Mei 2012

\begin{tabular}{cccc}
\hline \multirow{2}{*}{ No } & \multirow{2}{*}{ Tingkat pengetahuan } & \multicolumn{2}{c}{ Jumlah } \\
\cline { 3 - 4 } & & n (frekuensi) & \% (persentase) \\
\hline 1 & Sangat baik & 2 & 5,0 \\
2 & Baik & 22 & 55,0 \\
3 & Cukup & 13 & 32,5 \\
4 & Kurang & 3 & 7,5 \\
\hline & Total & $\mathbf{4 0}$ & $\mathbf{1 0 0 , 0}$ \\
\hline
\end{tabular}


Tabel 3. Distribusi frekuensi gambaran Sikap Responden Tentang Upaya Pencegahan Kaki Diabetik di Ruang Sahadewa dan Nakula RSUD Sanjiwani Gianyar, Maret - Mei 2012

\begin{tabular}{cccc}
\hline \multirow{2}{*}{ No } & \multirow{2}{*}{ Sikap } & \multicolumn{2}{c}{ Jumlah } \\
\cline { 3 - 4 } & & n (frekuensi) & \% (persentase) \\
\hline 1 & Sangat baik & 2 & 5,0 \\
2 & Baik & 32 & 80,0 \\
3 & Cukup & 6 & 15,0 \\
\hline \multicolumn{2}{r}{ Total } & $\mathbf{4 0}$ & $\mathbf{1 0 0 , 0}$ \\
\hline
\end{tabular}

Tabel 4. Distribusi frekuensi gambaran Tindakan Responden Dalam Upaya Pencegahan Kaki Diabetik di Ruang Sahadewa dan Nakula RSUD Sanjiwani Gianyar, Maret - Mei 2012

\begin{tabular}{cccc}
\hline \multirow{2}{*}{ No } & \multirow{2}{*}{ Tindakan } & \multicolumn{2}{c}{ Jumlah } \\
\cline { 3 - 4 } & Sangat baik & n (frekuensi) & \% (persentase) \\
\hline 1 & Baik & 28 & 2,5 \\
2 & Cukup & 11 & 70,0 \\
3 & Total & $\mathbf{4 0}$ & 27,5 \\
\hline & & & $\mathbf{1 0 0 , 0}$ \\
\hline
\end{tabular}

Tabel 5. Distribusi frekuensi gambaran perilaku respoden dalam upaya pencegahan kaki diabetes di Ruang Sahadewa dan Nakula RSUD Sanjiwani Gianyar, Maret - Mei 2012

\begin{tabular}{cccc}
\hline \multirow{2}{*}{ No } & \multirow{2}{*}{ Perilaku } & \multicolumn{2}{c}{ Jumlah } \\
\cline { 3 - 4 } & & n (frekuensi) & \% (persentase) \\
\hline 1 & Sangat baik & 2 & 5,0 \\
2 & Baik & 27 & 67,5 \\
3 & Cukup & 11 & 27,5 \\
\hline \multicolumn{2}{r}{ Total } & $\mathbf{4 0}$ & $\mathbf{1 0 0 , 0}$ \\
\hline
\end{tabular}

\section{PEMBAHASAN}

\section{Pengetahuan}

Berdasarkan hasil analisa data tingkat pengetahuan responden sebanyak 22 responden (55\%) pengetahuannya baik, tetapi masih ada juga responden yang memiliki pngetahuan kurang $(7,5 \%)$ dalam upaya pencegahan kaki diabetik. Hal ini disebabkan karena masih rendahnya tingkat pendidikan responden yaitu sebagian besar responden tingkat pendidikannya SD (42,5\%). Dan hanya 7,5\% tingkat pendidikannya perguruan tinggi. Menurut Mubarak, (2007) semakin tinggi pendidikan seseorang semakin mudah mereka menerima informasi, dan pada akhirnya semakin banyak juga pengetahuan yang dimiikinya. 


\section{Sikap}

Sikap merupakan suatu respon yang masih tertutup dari seseorang terhadap suatu stimulus atau objek, megubah sikap penderita diabetes melitus bukan pekerjaan yang mudah bahkan lebih sulit dari pada meningkatkan pengetahuan (Sunaryo, 2004). Dalam penelitian ini sikap responden dalam upaya pencegahan kaki diabetik rata rata baik yaitu sebanyak 32 responden (80\%), tetapi masih ada responden yang memiliki sikap dalam kategori cukup yaitu sebanyak 6 responden (15\%). Hal ini terlihat masih ada responden yang menganggap bahwa luka kecil pada kaki tidak perlu segera diobati dan akan sembuh dengan cepat.

Pada dasarnya sikap seseorang sangat dipengaruhi oleh tingkat pengetahuan, semakin tinggi tingkat pengetahuan seseorang semakin baik pula sikap seseorang dalam menilai suatu stimulus yang dihadapinya. Dalam mengubah sikap diperlukan keterampilan pendidik untuk memotivasi penderita diabetes melitus. Adapun teknik motivasi yang disarankan menurut Soegondo, dkk (2006) antara lain teknik motivasi secara persuasip aduakatif adalah suatu cara memotivasi sasaran dengan membujuk dan mengajak sasaran ataupun teknik motivasi dengan cara penerangan atau penyadaran.

\section{Tindakan}

Dari data menunjukan masih ada responden yang tidak secara rutin memeriksakan kaki ketempat pelayanan kesehatan atau ke dokter dengan alasan karena mereka tidak mengetahui akan pentingnya memeriksakan kaki ke dokter secara rutin dan responden menganggap tujuan utama mereka datang ke dokter atau kepelayanan kesehatan untuk memeriksakan penyakitnya dan mendapatkan obat. Menurut Tambunan dalam Soegondo, dkk (2006) yaitu pasien diabetes melitus harus memeriksakan kaki secara berkala dan rutin hal ini penting untuk mengetahui masalah - masalah kecil yang muncul pada kaki sedini mungkin.

\section{Gambaran Perilaku Responden Dalam Upaya Pencegahan Kaki Diabetik}

Berdasarkan hasil penelitian kebanyakan responden memiliki perilaku dalam kategori baik yaitu sebanyak 27 responden (67,5\%), tetapi masih ada responden yang memiliki perilaku dalam kategori cukup yaitu sebanyak 11 responden $(27,5 \%)$. 
Perilaku pencegahan kaki diabetik yang dilakukan oleh penderita diabetes melitus meliputi tiga komponen yaitu pengetahuan, sikap dan tindakan. Setiap komponen ini memiliki keterkaitan antara yang satu dengan yang lainnya. Pengetahuan penderita diabetes melitus tentang upaya pencegahan kaki diabetik bisa ditingkatkan melalui promosi dan penyuluhan tentang pencegahan kaki diabetik. Sikap dapat dirubah kearah yang positif melalui pemberian motivasi dan tindakan dapat dirubah dengan penyediaan faktor - faktor pendukung seperti fasilitas dan dukungan dari keluaraga atau pun lingkungan. Apabila ketiga komponen perilaku tersebut dapat berjalan dan dipatuhi oleh penderita diabetes melitus maka komplikasi kaki diabetik dapat dicegah secara dini.

Berhasilnya perawatan pada penderita diabetes melitus tergantung pada kerjasama antara petugas kesehatan dengan penderita diabetes melitus dan keluarganya itu sendiri. Bagi penderita diabetes melitus yang masih memiliki perilaku dalam kategori cukup masih sangat perlu ditingkatkan menjadi kategori sangat baik, karena perilaku yang masih dalam kategori cukup kemungkinan untuk terkena komplikasi kaki diabetik masih sangat tinggi.

\section{SIMPULAN DAN SARAN}

Gambaran perilaku pasien DM dalam upaya pencegahan kaki diabetik di ruang Sahadewa dan Nakula RSUD Sanjiwani Gianyar rata-rata dalam kategori baik. Faktor-faktor yang dinilai dalam upaya pencegahan kaki diabetik adalah pengetahuan, sikap, dan tindakan, ketiga faktor ini memiliki keterkaitan satu sama lainya dalam membentuk perilaku. Hasil yang didapatkan dari masing-masing faktor rata-rata masuk dalam kategori baik. Diharapkan pasien dan keluarga ikut serta dalam perawatan dirinya maupun angota keluarganya yang mengalami diabetes melitus sehingga terjadi hubungan timbal balik antara pasien dan keluarga dengan petugas kesehatan untuk mencapai derajat kesehatan yang optimal. 


\section{DAFTAR PUSTAKA}

Majalah kesehatan. (2012). 7 Langkah Mencegah Ulkus Kaki Diabetik. Diakses 2 Februari 2012, dari http://www.majalahkesehatan.com

Mubarak,W.I., dkk. (2007). Promosi Kesehatan Sebuah Pengantar Proses Belajar Mengajar dalam Pendidikan. Yogyakarta: Graha Ilmu.

Mubarak. (2007). Faktor-Faktor Yang Mempengaruhi Pengetahuan. Yogyakarta: Graha Ilmu

Notoatmojo, S. (2010). Metodologi Penelitian Kesehatan. Jakarta: Rineka Cipta

Nursalam. (2008). Konsep dan Penerapan Metodologi Penelitian Ilmu Keperawatan Pedoman Skripsi, Tesis, dan Instrumen Penelitian Keperawatan. Edisi II. Jakarta: Salemba Medika.

PERKENI. (2009). Pedoman Penatalaksanaan Kaki Diabetik. Jakarta: PB. PERKENI.

Soegondo,S.,dkk. (2006). Penatalaksanaan Diabetes Melitus Terpadu. Jakarta: FKUI.

Sudoyo, A. W, dkk. (2009). Buku Ajar Ilmu Penyakit Dalam. Jakarta: Interna Publising.

Sugiyono. (2001). Metode Penelitian. Bandung:Alfabeta

Sunaryo. (2004). Psikologi Untuk Keperawatan. Jakarta: Penerbit Buku Kedokteran EGC. 